\title{
PENGARUH MODEL SERAT PADA BAHAN FIBERGLASS TERHADAP KEKUATAN, KETANGGUHAN, DAN KEKERASAN MATERIAL
}

Oleh :

\section{WENDY TRIADJI NUGROHO *)}

\begin{abstract}
ABSTRAK
Fiberglass merupakan bahan yang sudah dikenal luas penggunaanya. Ia dapat dijadikan bahan alternatif pengganti plastik yang memiliki kekuatan lebih tinggi. Di bidang otomotif, fiberglass dipakai untuk berbagai asesoris maupun suku cadang.

Tahapan-tahapan penelitian yang dilakukan adalah studi literatur, menyiapkan alat dan bahan, melakukan pengujian tarik, ketangguhan, dan kekerasan, mencatat data dari alat ukur, melakukan analisis data, serta menarik kesimpulan.

Hasil analisis data menunjukkan bahwa kekuatan dan ketangguhan tertinggi miliki oleh material fiber dengan pola serat WR 400 dengan nilai 191 Newton dan 5,36 Joule. Nilai-nilai tersebut lebih tinggi dari yang dicapai oleh material plastik, yaitu 23 Newton untuk kekuatan tarik dan 0,64 Joule untuk ketangguhannya. Hal ini membuktikan bahwa fiberglass dengan pola serat seperti WR 400 mempunyai kekuatan dan ketangguhan yang lebih baik dari plastik.
\end{abstract}

Kata kunci : Fiberglass, uji tarik, uji ketangguhan, uji kekerasan

\section{PENDAHULUAN}

\section{Latar Belakang}

Fiberglass atau dalam bahasa Indonesia dikenal sebagai kaca serat dan serat gelas merupakan kaca cair yang ditarik menjadi serat tipis dengan diameter sekitar 0,005 sampai dengan $0,01 \mathrm{~mm}$. Serat ini selanjutnya dipintal menjadi benang atau ditenun menjadi kain kemudian diresapi dengan resin sehingga menjadi material yang kuat dan tahan korosi. Fiberglass memiliki banyak kegunaan seperti dalam pembuatan perahu, mobil, tangki air, atap, perpipaan, pelapisan (coating), dan lain-lain.

Pembuatan fiberglass tidak terlalu sulit. Bahan utamanya terdiri dari tiga bagian, yaitu serat, resin dan katalis. Penelitian ini bermaksud untuk mengetahui kekuatan, ketangguhan, dan kekerasan material fiberglass berdasarkan variasi pola serat dengan mempertahankan komposisi resin dan katalis. Selanjutnya sifat-sifat material tersebut dibandingkan dengan sifat material plastik yang digunakan sebagai bahan pembuat spare part kendaraan bermotor.

\section{Permasalahan}

Masalah yang ingin diteliti adalah menentukan nilai kekuatan, ketangguhan dan kekerasan material fiberglass dibandingkan dengan material plastik.

\section{Batasan Masalah}

Ruang lingkup penelitian adalah :

- waktu pengambilan data adalah antara bulan Desember 2104 sampai dengan April 2015

- posisi material uji dianggap homogen

- bahan yang dipakai dalam kasus ini adalah fiberglass dengan pola serat WR 400, WR 200, serabut dan plastik

- $\quad$ pengujian material hanya terbatas pada uji tarik, uji ketangguhan, dan uji kekerasan.

\section{Tujuan Penelitian}

Tujuan yang ingin dicapai dalam penelitian ini adalah mengetahui nilai kekuatan, ketangguhan dan kekerasan tertinggi dari material fiber dengan beberapa model serat serta nilai ketangguhan material fiber dengan material plastik

\section{METODOLOGI}

\section{Waktu dan Tempat Penelitian}

Penelitian dilaksanakan pada bulan Desember 2014 sampai dengan bulan April 2015. Sedangkan tempat penelitian adalah di Laboratorium Teknik Otomotif Politeknik Negeri Jember. 


\section{Bahan dan Alat}

Bahan yang digunakan adalah fiberglass dengan pola serat WR 400, WR 200, dan serabut serta plastik. Bahan ini merupakan perpaduan dari resin, talk, dan variasi dari tiga pola serat, yaitu WR 400, WR 200, dan serabut. Adapun untuk bahan plastik, ia diperoleh melalui pengadaan langsung. Tujuannya adalah membandingkan sifat material fiber dengan sifat material plastik. Sedangkan peralatan yang dipakai adalah timbangan digital, strain gauge, alat uji tarik, alat uji ketangguhan, dan alat uji kekerasan.

\section{Metode Pelaksanaan}

\subsection{Penimbangan Katalis}

Penimbangan katalis yang merupakan tahan penyiapan bahan ditunjukkan oleh Gambar 1 di bawah ini.

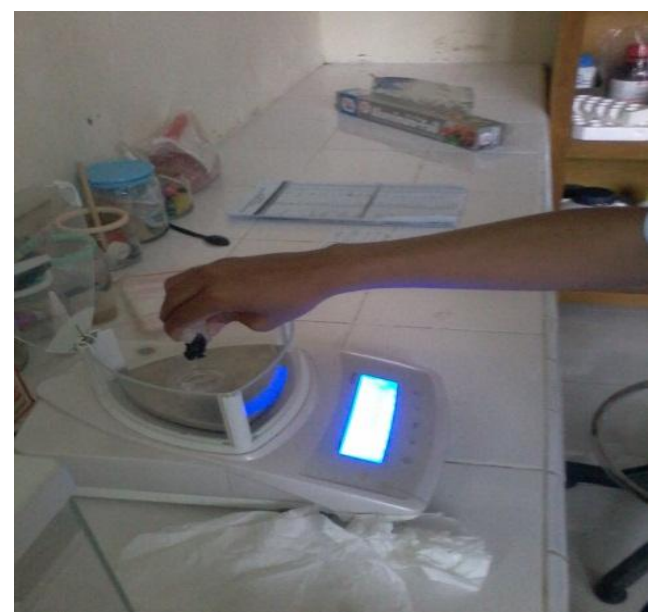

Gambar 1. Menimbang katalis

\subsection{Pemanasan Plastik}

Plastik perlu dipanaskan untuk membuat fiberglass sesuai dengan bentuk yang diinginkan. Pemanasan plastik ini didokumentasikan dalam Gambar 2.

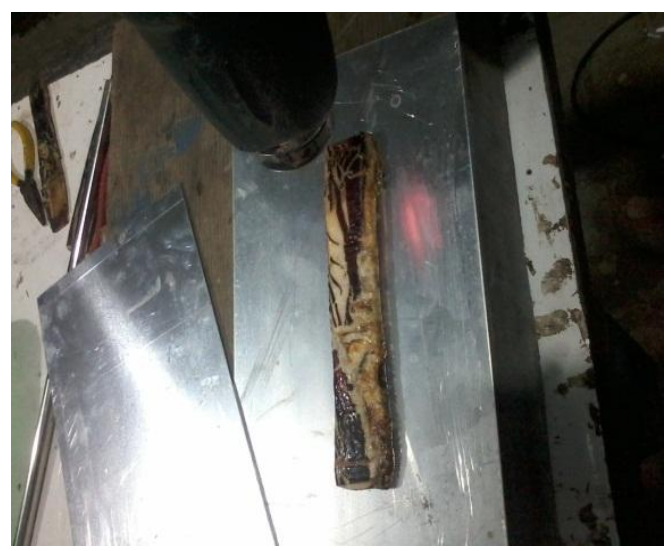

Gambar 2.Pemanasan bodi plastik

\subsection{Penimbangan Beban}

Beban dapat ditentukan dengan presisi melalui proses penimbangan yang dinyatakan oleh

Gambar 3

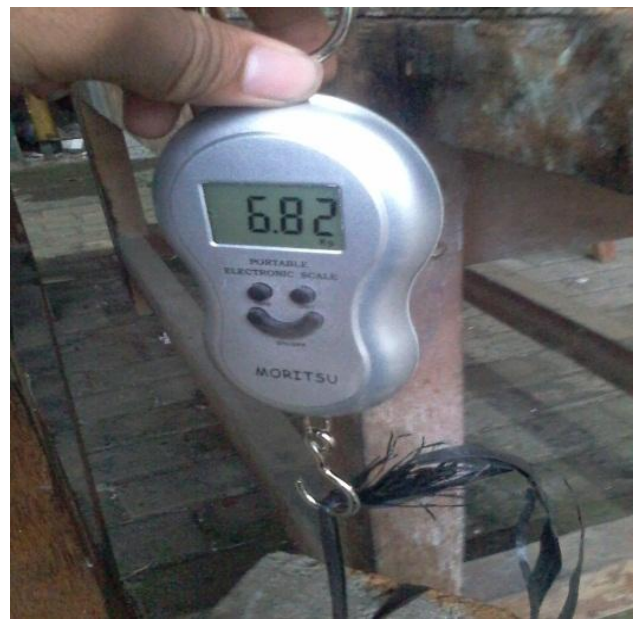

Gambar 3. Menimbang beban

\subsection{Membuat Cetakan Material Uji Tarik}

Untuk membuat spesimen tarik diperlukan cetakan/pola. Cetakan/pola spesimen tarik disajikan oleh Gambar 4 berikut ini.

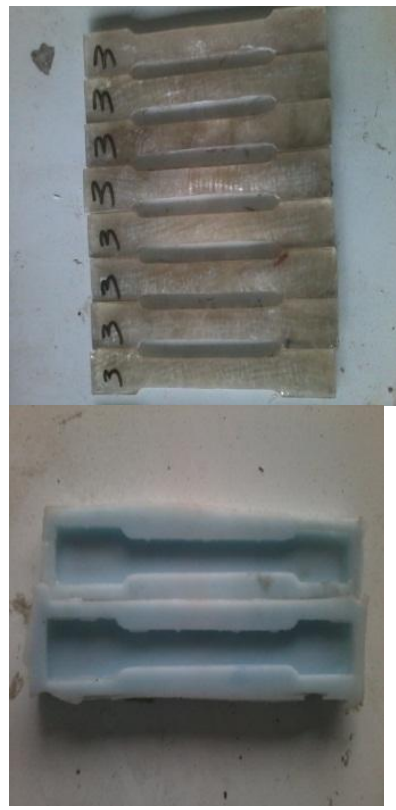

Gambar 4. Komposit uji tarik 


\section{DATA HASIL PENGUKURAN DAN PEMBAHASAN}

Spesimen yang digunakan untuk penelitian ini adalah fiber dengan bahan dasar resin dan katalis dengan kompposisi tertentu yang diperkuat dengan serat. Adapun serat yang digunakan ada tiga macam pola, yaitu WR 400, WR 200, dan serabut.

\section{Hasil Uji Tarik}

\subsection{Material fiber dengan pola serat WR 400}

Hasil pengujian tarik dari bahan fiber dengan pola serat WR 400, memperoleh data sebagai berikut.

Tabel1. Hasil uji tarik spesimen fiber + WR400

\begin{tabular}{|c|c|c|c|c|c|c|c|c|c|}
\hline 1 & \multicolumn{2}{|c|}{2} & \multicolumn{2}{|c|}{3} & \multicolumn{2}{|c|}{4} & \multicolumn{2}{|c|}{5} & \\
\hline $\begin{array}{c}\text { specimen } \\
\text { WR 400 }\end{array}$ & $\begin{array}{r}\text { specin } \\
4 \\
\end{array}$ & WR & $\begin{array}{c}\text { spec } \\
\text { WR }\end{array}$ & & specir & WR & $\begin{array}{c}\text { spec } \\
\text { WR }\end{array}$ & & \\
\hline $\mathrm{N}$ & $\begin{array}{c}\mathrm{L} \\
(\mathrm{mm})\end{array}$ & $\mathrm{N}$ & $\begin{array}{c}\mathrm{L} \\
(\mathrm{mm})\end{array}$ & $\mathrm{N}$ & $\begin{array}{c}\mathrm{L} \\
(\mathrm{mm})\end{array}$ & $\mathrm{N}$ & $\begin{array}{c}\mathrm{L} \\
(\mathrm{mm})\end{array}$ & $\mathrm{N}$ & $\begin{array}{c}\mathrm{L} \\
(\mathrm{mm})\end{array}$ \\
\hline 0 & 0,076 & 0 & 0,029 & 0 & 0,058 & 0 & 0,266 & 0 & 0,425 \\
\hline 1 & 1,065 & 0 & 0,045 & 0 & 0,197 & 1 & 0,266 & 1 & 0,582 \\
\hline 2 & 1,066 & 1 & 0,045 & 0 & 0,394 & 2 & 0,746 & 2 & 0,755 \\
\hline 12 & 1,802 & 11 & 2,094 & 12 & 0,538 & 3 & 1,556 & 2 & 1,181 \\
\hline 22 & 2,72 & 10 & 2,893 & 11 & 1,074 & 15 & 1,656 & 3 & 1,181 \\
\hline 21 & 2,72 & 14 & 3,199 & 35 & 1,074 & 15 & 1,875 & 3 & 1,639 \\
\hline 33 & 3,805 & 26 & 3,745 & 23 & 1,346 & 27 & 2,866 & 14 & 1,649 \\
\hline 63 & 4,866 & 26 & 4,404 & 41 & 1,348 & 45 & 4,005 & 23 & 2,957 \\
\hline 63 & 4,867 & 56 & 5,368 & 53 & 1,348 & 91 & 4,882 & 23 & 3,871 \\
\hline 137 & 5,925 & 106 & 6,578 & 53 & 2,357 & 88 & 5,106 & 21 & 4,8 \\
\hline 104 & 5,986 & 76 & 6,541 & 63 & 3,503 & 164 & 5,187 & 56 & 4,797 \\
\hline 169 & 6,642 & 95 & 6,541 & 6 & 3,503 & 141 & 6,095 & 56 & 5,953 \\
\hline 10 & 7,595 & 95 & 7,665 & 6 & 3,909 & 191 & 6,415 & 66 & 7,136 \\
\hline 6 & 8,978 & 10 & 8,115 & 5 & 6,311 & 10 & 7,834 & 5 & 7,346 \\
\hline
\end{tabular}

Dari Tabel 1 di atas apabila dibuat grafiknya akan tampak seperti Gambar 5.

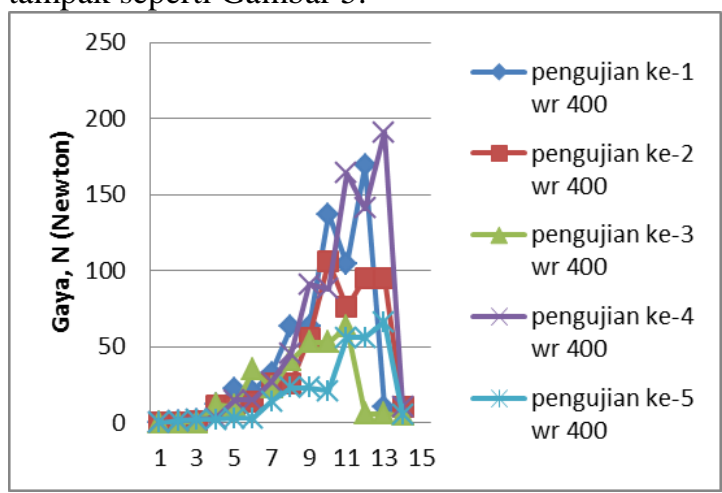

Dari Gambar 5 di atas dapat kita lihat bahwa nilai kekuatan tarik (tensile strength) tertinggi dari fiber dengan pola serat WR 400 dicapai pada pengujian ke-4 sebesar $191 \mathrm{~N}$.
Sedangkan nilai terendahnya dicapai pada pengujian ke-3 sebesar 63 Newton.

\subsection{Material fiber dengan pola serat WR 200}

Hasil pengujian tarik dari bahan fiber dengan pola serat WR 200 diperoleh data sebagai berikut.

Tabel 2. Hasil uji tarik spesimen fiber + WR200

\begin{tabular}{|c|c|c|c|c|c|c|c|c|c|}
\hline & 1 & & 2 & & 3 & & 4 & & 5 \\
\hline & $\begin{array}{l}\text { cimen } \\
200\end{array}$ & & $\begin{array}{l}\text { cimen } \\
200\end{array}$ & spec & $\begin{array}{l}\text { een WR } \\
00\end{array}$ & & imen & & imen \\
\hline $\mathrm{N}$ & $\begin{array}{c}\mathrm{L} \\
(\mathrm{mm})\end{array}$ & $\mathrm{N}$ & $\begin{array}{c}\mathrm{L} \\
(\mathrm{mm})\end{array}$ & $\mathrm{N}$ & $\begin{array}{c}\mathrm{L} \\
(\mathrm{mm})\end{array}$ & $\mathrm{N}$ & $\begin{array}{c}\mathrm{L} \\
(\mathrm{mm})\end{array}$ & $\mathrm{N}$ & $\begin{array}{c}\mathrm{L} \\
(\mathrm{mm})\end{array}$ \\
\hline 1 & 0,043 & 2 & 1,72 & 1 & 0,83 & 0 & 0,02 & 0 & 0,015 \\
\hline 2 & 1,39 & 2 & 2,025 & 13 & 1,94 & 1 & 0,237 & 0 & 0,063 \\
\hline 2 & 1,97 & 3 & 2,559 & 13 & 2,786 & 1 & 0,851 & 0 & 0,084 \\
\hline 3 & 2,288 & 4 & 2,896 & 13 & 2,933 & 12 & 1,599 & 1 & 0,575 \\
\hline 3 & 3,072 & 4 & 3,481 & 27 & 3,867 & 11 & 1,6 & 1 & 0,801 \\
\hline 3 & 3,144 & 5 & 3,758 & 37 & 5,286 & 23 & 2,308 & 10 & 1,275 \\
\hline 14 & 3,154 & 16 & 4,691 & 36 & 5,432 & 22 & 3,052 & 22 & 2,543 \\
\hline 24 & 4,588 & 26 & 5,563 & 53 & 6,749 & 20 & 3,195 & 29 & 2,543 \\
\hline 14 & 4,826 & 16 & 5,594 & 42 & 6,685 & 41 & 4,217 & 29 & 2,407 \\
\hline 31 & 5,948 & 30 & 6,581 & 28 & 7,401 & 24 & 4,272 & 60 & 3,545 \\
\hline 45 & 7,427 & 51 & 7,063 & 28 & 7,419 & 10 & 5,418 & 41 & 3,53 \\
\hline 43 & 7,439 & 44 & 7,893 & 81 & 8,606 & 9 & 6,42 & 3 & 5,006 \\
\hline 57 & 8,703 & 71 & 8,707 & 106 & 8,891 & 8 & 7,316 & 2 & 5,021 \\
\hline 3 & 10,076 & 65 & 9,916 & 6 & 9,652 & 8 & 7,342 & 2 & 6,26 \\
\hline 2 & 10,076 & 9 & 10,252 & 5 & 10,663 & 7 & 8,034 & 1 & 7,297 \\
\hline 2 & 10,763 & 8 & 11,849 & 5 & 10,96 & 7 & 8,948 & & \\
\hline 2 & 10,998 & 5 & 11,993 & & & & & & \\
\hline
\end{tabular}

Grafik dari Tabel 2 adalah sebagai berikut.

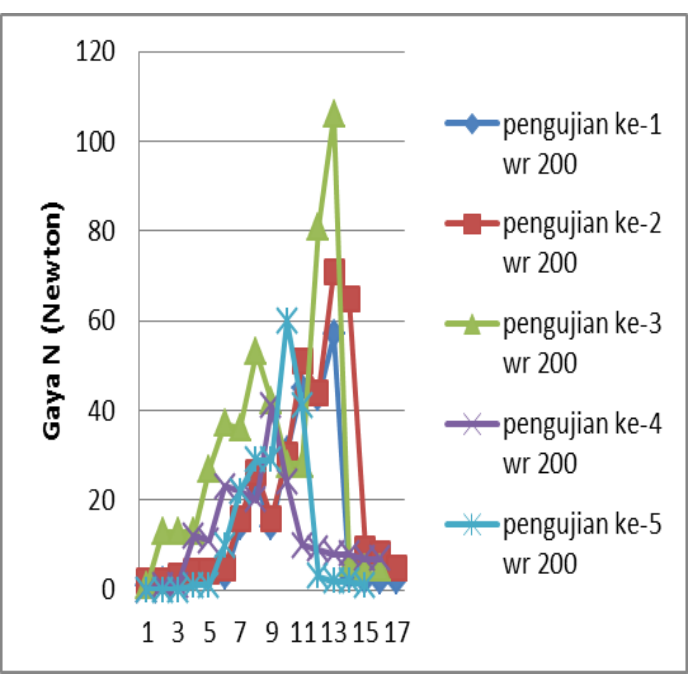

Gambar 5. Hasil uji tarik spesimen fiber $+W R$

Nilai kekuatan tarik tertinggi untuk bahan fiber berpola serat WR 200 diperoleh saat pengujian ke-3 sebesar $106 \mathrm{~N}$, sedangkan nilai 
terendahnya didapat saat pengujian ke-4 sebesar 41 Newton.

\begin{tabular}{|c|c|c|c|c|c|c|c|c|c|}
\hline & 1 & & & 3 & & 4 & & 5 & \\
\hline & en Serabut & & & $\begin{array}{l}\text { specim } \\
\text { Serab }\end{array}$ & & $\begin{array}{l}\text { specin } \\
\text { Serab }\end{array}$ & & $\begin{array}{l}\text { specir } \\
\text { Seral }\end{array}$ & \\
\hline $\mathrm{N}$ & $\mathrm{L}(\mathrm{mm})$ & $\mathrm{N}$ & $\mathrm{L}(\mathrm{mm})$ & $\mathrm{N}$ & $\mathrm{L}(\mathrm{mm})$ & $\mathrm{N}$ & $\mathrm{L}(\mathrm{mm})$ & $\mathrm{N}$ & $\mathrm{L}(\mathrm{mm})$ \\
\hline 1 & 0,043 & 1 & 0,015 & 1 & 0,09 & 0 & 0,041 & 0 & 0,042 \\
\hline 1 & 0,092 & 1 & 0,769 & 2 & 0,094 & 0 & 0,202 & 0 & 0,056 \\
\hline 12 & 0,12 & 13 & 0,769 & 3 & 0,67 & 1 & 0,962 & 1 & 0,558 \\
\hline 12 & 0,734 & 13 & 1,083 & 4 & 0,71 & 2 & 1,269 & 2 & 0,683 \\
\hline 11 & 0,734 & 42 & 1,515 & 16 & 1,738 & 2 & 2,19 & 2 & 0,839 \\
\hline 11 & 0,789 & 42 & 2,702 & 16 & 1,828 & 2 & 2,882 & 2 & 0,745 \\
\hline 22 & 1,485 & 27 & 2,702 & 29 & 2,652 & 3 & 2,883 & 3 & 0,731 \\
\hline 21 & 1,514 & 55 & 2,671 & 27 & 2,651 & 3 & 3,408 & 3 & 1,902 \\
\hline 54 & 1,514 & 41 & 4,014 & 6 & 4,635 & 4 & 4,66 & 4 & 2,971 \\
\hline 54 & 3,508 & 41 & 4,025 & 5 & 9,836 & 4 & 5,704 & 4 & 3,058 \\
\hline 5 & 3,508 & 4 & 5,436 & & & 4 & 7,734 & 4 & 3,922 \\
\hline 5 & 3,523 & & & & & 5 & 6,396 & 4 & 4,274 \\
\hline 4 & 4,9 & & & & & 7 & 7,526 & 4 & 4,818 \\
\hline 4 & 6,073 & & & & & 18 & 9,938 & 4 & 5,54 \\
\hline & & & & & & 17 & 10,982 & 4 & 5,551 \\
\hline & & & & & & 51 & 10,993 & 4 & 6,73 \\
\hline & & & & & & 86 & 10,993 & 4 & 8,126 \\
\hline & & & & & & 69 & 10,993 & 5 & 8,876 \\
\hline & & & & & & 22 & 10,993 & 5 & 9,839 \\
\hline & & & & & & 6 & 10,994 & 5 & 10,09 \\
\hline & & & & & & 5 & 10,994 & 7 & 10,868 \\
\hline & & & & & & & & 17 & 10,868 \\
\hline & & & & & & & & 26 & 10,868 \\
\hline & & & & & & & & 23 & 10,868 \\
\hline & & & & & & & & 52 & 10,868 \\
\hline & & & & & & & & 36 & 10,868 \\
\hline & & & & & & & & 46 & 10,868 \\
\hline & & & & & & & & 57 & 10,868 \\
\hline & & & & & & & & 14 & 10,868 \\
\hline & & & & & & & & 3 & 10,87 \\
\hline
\end{tabular}

\subsection{Material fiber dengan pola serat Serabut}

Hasil pengujian tarik dari bahan fiber dengan pola serat Serabut diperoleh data sebagai berikut.

Tabel 3. Hasil uji tarik spesimen fiber + Serabut

Grafik dari data-data yang ada dalam Tabel 3 adalah sebagaimana dinyatakan oleh Gambar 6.

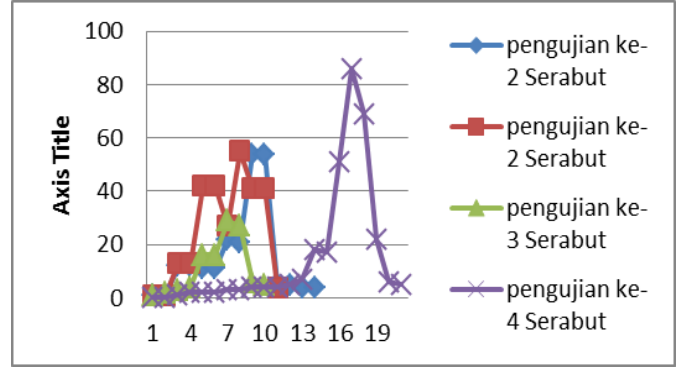

Gambar 6.Hasil uji tarik spesimen fiber + WR 200

Dari Gambar 6 dapat diketahui bahwa tensile strength tertinggi material fiber dngan pola serat serabut dicapai pada pengujian ke-4 sebesar 86 Newton, sedangkan nilai trndahnya adalah 27 Newton.

\subsection{Material Plastik}

Hasil pengujian tarik dari bahan Plastik diperoleh data sebagai berikut.

Tabel 4. Hasil uji tarik spesimen Plastik

\begin{tabular}{|r|r|r|r|r|r|r|r|r|r|}
\hline \multicolumn{2}{|c|}{1} & \multicolumn{2}{c|}{2} & \multicolumn{2}{|c|}{3} & \multicolumn{2}{c|}{4} & \multicolumn{2}{c|}{5} \\
\hline \multicolumn{2}{|c|}{$\begin{array}{c}\text { specimen } \\
\text { Plastik }\end{array}$} & \multicolumn{2}{c|}{$\begin{array}{c}\text { specimen } \\
\text { Plastik }\end{array}$} & \multicolumn{2}{c|}{$\begin{array}{c}\text { specimen } \\
\text { Plastik }\end{array}$} & \multicolumn{2}{c|}{$\begin{array}{c}\text { specimen } \\
\text { Plastik }\end{array}$} & \multicolumn{2}{c|}{$\begin{array}{c}\text { specimen } \\
\text { Plastik }\end{array}$} \\
\hline $\mathrm{N}$ & $\mathrm{L}(\mathrm{mm})$ & $\mathrm{N}$ & $\begin{array}{c}\mathrm{L} \\
(\mathrm{mm})\end{array}$ & $\mathrm{N}$ & $\mathrm{L}(\mathrm{mm})$ & $\mathrm{N}$ & $\begin{array}{c}\mathrm{L} \\
(\mathrm{mm})\end{array}$ & $\mathrm{N}$ & $\begin{array}{c}\mathrm{L} \\
(\mathrm{mm})\end{array}$ \\
\hline 0 & 0,001 & 0 & 0,034 & 1 & 0,74 & 0 & 0,086 & 0 & 0,239 \\
\hline 0 & 0,002 & 0 & 0,085 & 2 & 1,245 & 0 & 0,229 & 1 & 0,305 \\
\hline 0 & 0,084 & 0 & 0,16 & 3 & 1,807 & 0 & 0,245 & 2 & 0,756 \\
\hline 0 & 0,157 & 1 & 0,861 & 4 & 1,807 & 0 & 0,848 & 3 & 0,756 \\
\hline 0 & 0,144 & 2 & 1,143 & 4 & 2,08 & 1 & 0,848 & 3 & 0,766 \\
\hline 0 & 0,292 & 3 & 1,863 & 4 & 2,958 & 2 & 1,855 & 14 & 1,946 \\
\hline 1 & 0,923 & 3 & 1,889 & 4 & 3,737 & 3 & 1,867 & 13 & 1,893 \\
\hline 1 & 0,869 & 16 & 3,081 & 4 & 4,012 & 14 & 2,989 & 13 & 2,589 \\
\hline 2 & 2,064 & 15 & 3,288 & 4 & 4,492 & 13 & 2,989 & 14 & 2,857 \\
\hline 13 & 2,064 & 5 & 4,36 & 4 & 5,016 & 24 & 4,107 & 6 & 3,397 \\
\hline 13 & 2,912 & & & 4 & 5,017 & 23 & 4,332 & 6 & 4,193 \\
\hline 8 & 3,241 & & & & & 23 & 5,169 & 5 & 5,474 \\
\hline 7 & 4,51 & & & & & 5 & 6,679 & & \\
\hline 6 & 5,707 & & & & & 4 & 7,913 & & \\
\hline 6 & 5,708 & & & & & & & & \\
\hline
\end{tabular}

Grafik dari data-data yang ada dalam Tabel 4 adalah sebagaimana dinyatakan oleh Gambar 7. 


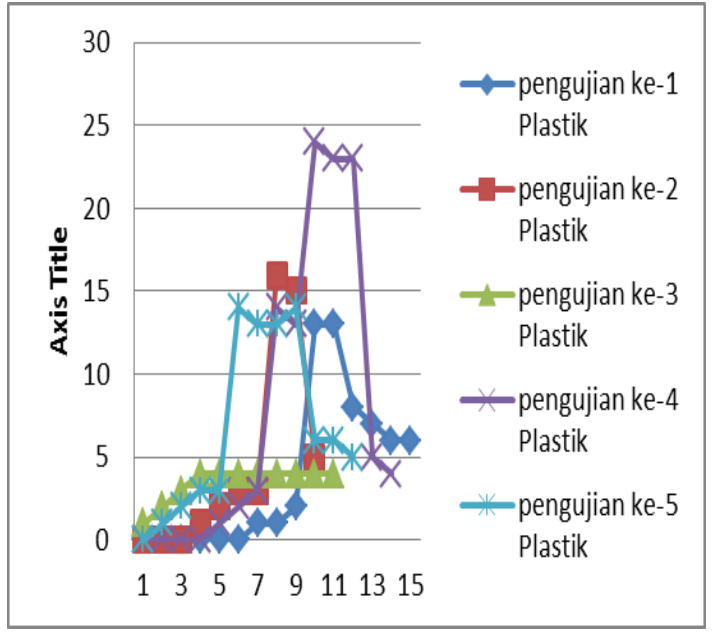

Gambar 7. Hasil uji tarik spesimen Plastik

Dari Gambar 7 dan Tabel 4, dapat diketahui bahwa nilai kekuatan tarik terbesar untuk material plastik terjadi saat pengujian ke-4 sebesar 23 Newton, sedangkan nilai terndahnya dicapai saat pengujian ke-1 sebesar 13 Newton.

\section{Hasil Uji Ketangguhan (Impak)}

\subsection{Spesimen Fiber + WR 400}

Spesifikasi Specimen WR 400

- Resin $20 \mathrm{ml}$

- Catalist 17 tetes=0,6088 gram

- Membuat 5 speciment

- Proses pengerasan 3 hari

- Pola serat WR 400

- Menggunakan 6 lapis

Tabel 5. Hasil uji ketangguhan spesimen Fiber dengan pola serat WR 400

\begin{tabular}{|l|l|l|l|l|l|}
\hline \multicolumn{7}{|c|}{ Speciment Fiber + Pola serat WR 400 } \\
\hline No. & $\begin{array}{l}\text { Energy } \\
(\mathrm{J})\end{array}$ & $\begin{array}{l}\text { Angle } \\
(\ldots)^{\circ}\end{array}$ & $\begin{array}{l}\text { Standart } \\
\text { pandulum }\end{array}$ & $\begin{array}{l}\text { Metod } \\
\mathrm{e}\end{array}$ \\
\hline 1 & 4,99 & 1,71 & $\begin{array}{l}\text { ISO } \\
13802\end{array}$ & $5 \mathrm{~J}$ & $\begin{array}{l}\text { Charp } \\
\text { y }\end{array}$ \\
\hline 2 & 5,399 & 0,36 & $\begin{array}{l}\text { ISO } \\
13802\end{array}$ & $5,4 \mathrm{~J}$ & $\begin{array}{l}\text { Charp } \\
\mathrm{y}\end{array}$ \\
\hline 3 & 5,483 & 3,33 & $\begin{array}{l}\text { ASTM } \\
\text { D 256 }\end{array}$ & $5,5 \mathrm{~J}$ & Izod \\
\hline 4 & 5,486 & 2,34 & $\begin{array}{l}\text { ASTM } \\
\text { D 256 }\end{array}$ & $5,5 \mathrm{~J}$ & Izod \\
\hline 5 & 5,382 & 15,3 & $\begin{array}{l}\text { ASTM } \\
\text { D 256 }\end{array}$ & $5,5 \mathrm{~J}$ & Izod \\
\hline
\end{tabular}

Dari kelima pengujian ketangguhan, energi yang dibutuhkan untuk mematahkan material WR 400 sebesar 5,36 Joule.

\subsection{Spesimen Fiber + WR 200}

Spesifikasi Spesimen WR 200

- $\quad$ Resin $20 \mathrm{ml}$

- Catalist 17 tetes=0,6088 gram
- Membuat 5 speciment

- Proses pengerasan 3 hari

- Pola serat WR 200

- Menggunakan 6 lapis

Tabel 6. Hasil uji ketangguhan spesimen Fiber dengan pola serat WR 200

\begin{tabular}{|l|l|l|l|l|l|}
\hline \multicolumn{7}{|l|}{ Speciment Fiber + Pola Serat WR 200 } \\
\hline No. & $\begin{array}{l}\text { Energy } \\
(\mathrm{J})\end{array}$ & $\begin{array}{l}\text { Angle } \\
(\ldots)^{\circ}\end{array}$ & Standart & $\begin{array}{l}\text { Massa } \\
\text { pandulum }\end{array}$ & $\begin{array}{l}\text { Meto } \\
\text { de }\end{array}$ \\
\hline 1 & 2,337 & 93,24 & $\begin{array}{l}\text { ASTM } \\
\text { D 256 }\end{array}$ & $5,5 \mathrm{~J}$ & Izod \\
\hline 2 & 1,896 & 101,79 & $\begin{array}{l}\text { ASTM } \\
\text { D 256 }\end{array}$ & $5,5 \mathrm{~J}$ & Izod \\
\hline 3 & 2,215 & 95,58 & $\begin{array}{l}\text { ASTM } \\
\text { D 256 }\end{array}$ & $5,5 \mathrm{~J}$ & Izod \\
\hline 4 & 3,169 & 77,13 & $\begin{array}{l}\text { ASTM } \\
\text { D 256 }\end{array}$ & $5,5 \mathrm{~J}$ & Izod \\
\hline 5 & 1,993 & 99,90 & $\begin{array}{l}\text { ASTM } \\
\text { D 256 }\end{array}$ & $5,5 \mathrm{~J}$ & Izod \\
\hline
\end{tabular}

Dari kelima pengujian ketangguhan, energi yang dibutuhkan untuk mematahkan material WR 200 sebesar 2,32 Joule.

\subsection{Spesifikasi Spesimen Fiber + Serabut} Spesifikasi Spesimen Serabut

- $\quad$ Resin $20 \mathrm{ml}$

- Catalist 17 tetes=0,6088 gram

- Membuat 5 speciment

- Proses pengerasan 3 hari

- Pola serat Serabut

- Menggunakan 6 lapis

Tabel 7. Hasil uji ketangguhan spesimen Fiber dengan pola serat Serabut

\begin{tabular}{|l|l|l|l|l|l|}
\hline \multicolumn{6}{|c|}{ Speciment Fiber + Pola Serat Serabut } \\
\hline No. & $\begin{array}{l}\text { Energy } \\
(\mathrm{J})\end{array}$ & $\begin{array}{l}\text { Angle } \\
(\ldots)^{\circ}\end{array}$ & $\begin{array}{l}\text { Standart } \\
\text { Massa } \\
\text { pandulum }\end{array}$ & $\begin{array}{l}\text { Meto } \\
\text { de }\end{array}$ \\
\hline 1 & 2,067 & 98,46 & $\begin{array}{l}\text { ASTM } \\
\text { D 256 }\end{array}$ & $5,5 \mathrm{~J}$ & Izod \\
\hline 2 & 2,482 & 90,45 & $\begin{array}{l}\text { ASTM } \\
\text { D 256 }\end{array}$ & $5,5 \mathrm{~J}$ & Izod \\
\hline 3 & 2,627 & 87,66 & $\begin{array}{l}\text { ASTM } \\
\text { D 256 }\end{array}$ & $5,5 \mathrm{~J}$ & Izod \\
\hline 4 & 2,814 & 84,06 & $\begin{array}{l}\text { ASTM } \\
\text { D 256 }\end{array}$ & $5,5 \mathrm{~J}$ & Izod \\
\hline 5 & 1,896 & 101,79 & $\begin{array}{l}\text { ASTM } \\
\text { D 256 }\end{array}$ & $5,5 \mathrm{~J}$ & Izod \\
\hline
\end{tabular}

Dari kelima pengujian ketangguhan, energi yang dibutuhkan untuk mematahkan material Serabut sebesar 2,38 Joule.

\subsection{Spesimen Plastik}

Spesifikasi Speciment Bodi Plastik

- Menggunakan bodi sepeda motor

- Proses pembentukan spesiment menggunakan blower panas

- Membuat 5 speciment 
- $\quad$ Proses pengerasan 3 hari

Tabel 8. Hasil uji ketangguhan spesimen plastik

\begin{tabular}{|l|l|l|l|l|l|}
\hline \multicolumn{2}{|c|}{ Speciment Plastik } \\
\hline No. & $\begin{array}{l}\text { Energy } \\
(\mathrm{J})\end{array}$ & $\begin{array}{l}\text { Angle } \\
\left(\ldots{ }^{\circ}\right.\end{array}$ & Standart & $\begin{array}{l}\text { Massa } \\
\text { pandulum }\end{array}$ & Metode \\
\hline 1 & 0,641 & 128,70 & $\begin{array}{l}\text { ASTM } \\
\text { D 256 }\end{array}$ & $5,5 \mathrm{~J}$ & Izod \\
\hline 2 & 0,764 & 125,73 & $\begin{array}{l}\text { ASTM } \\
\text { D 256 }\end{array}$ & $5,5 \mathrm{~J}$ & Izod \\
\hline 3 & 0,351 & 136,26 & $\begin{array}{l}\text { ASTM } \\
\text { D 256 }\end{array}$ & $5,5 \mathrm{~J}$ & Izod \\
\hline 4 & 0,623 & 129,15 & $\begin{array}{l}\text { ASTM } \\
\text { D 256 }\end{array}$ & $5,5 \mathrm{~J}$ & Izod \\
\hline 5 & 0,814 & 124,56 & $\begin{array}{l}\text { ASTM } \\
\text { D 256 }\end{array}$ & $5,5 \mathrm{~J}$ & Izod \\
\hline
\end{tabular}

Dari kelima pengujian ketangguhan, energi yang dibutuhkan untuk mematahkan material Plastik sebesar 0,64 Joule.

Dari Tabel 5 hingga 8 dapat kita ketahui bahwa nilai ketangguhan tertinggi dicapai oleh material fiber dengan pola serat WR 400 sebesar 5,36 Joule.

\section{Hasil Pengujian Kekerasan}

Hasil pengujian kekerasan untuk material fiberglass dengan pola serat WR 400, WR 200, maupun serabut menunjukkan hasil yang relatif sama, yaitu mendekati nol. Hal ini dikarenakan sifat dari fiberglass yang getas seperti kaca.

\section{KESIMPULAN DAN SARAN}

\section{Kesimpulan}

Material fiberglass memiliki sifat yang cukup unik. Kekuatan dan ketangguhannya bergantung pada pola serat penyusunnya.

Dari analisis dan pembahasan data yang telah dilakukan, maka dapat ditarik suatu kesimpulan bahwa nilai kekuatan dan ketangguhan tertinggi diperoleh oleh material fiber dengan pola serat WR 400.

Dari hasil pengujian tarik dan ketangguhan, terbukti bahwa materrial fiber dengan tiga macam pola serat memiliki kekuatan dan ketangguhan yang lebih tinggi daripada material plastik.

\section{Saran}

Untuk mendapatkan hasil pengujian yang lebih akurat sebaiknya dilakukan:

a. Penimbangan yang lebih hati-hati

b. Pembuatan pola yang cermat sesuai dengan standar yang disyaratkan

c. Kalibrasi alat uji yang digunakan d. Membaca hasil pengujian dengan hatihati.

\section{DAFTAR PUSTAKA}

Agarwal, B. D., L. J. 1990. "Analysis and Performance of Fibre Composites", John Wiley Inc., New York.

Asrikin. 2011. "Karakterisasi Fatigue Dan Analisa Mikroskpis pada Mekanisme Kegagalan Material Komposit Fiber Glass-Epoxy untuk Material Struktur Sudu Turbin Angin”, Universitas Indonesia.

ASTM E8. 1986. “ Metal Test Methods and Analytical Procedures", American Society for Testing Materials", Philadephia, PA.

Carli, S. A. Widyanto, Ismoyo Haryanto. 2012. "Analisis Kekuatan Tarik dan Lentur Komposit Serat Gelas Jenis Woven dengan Matriks Eppoxy dan Polyster Berlapis Simetri dengan Metoda Manufaktur Hand Lay-Up", Universitas Diponegoro Semarang.

Modul OPKR-60-029A. 2004. "Membuat (Fabrikasi) Komponen Fiberglass/Bahan Komposit", Tim Fakultas Teknik Universitas Negeri Yogyakarta.

Mujiarto, Iman. 2005. “ Sifat dan Karakteristik Material Plastik dan Bahan Aditif”, Staf Pengajar AMNI Semarang. 